\title{
Mother-Tongue Based (MTB) Schooling: A Key for Transforming Early Childhood Education for Future Generation in Nigeria
}

\author{
John A. Emenike ${ }^{1 *} \quad$ Antonia N. Ngwoke (Ph.D) ${ }^{2} \quad$ O.C. Njoku ${ }^{2}$ \\ 1. School of Early Childhood and Primary Education, Federal College of Education, \\ P.M.B 39 Kontagora, Niger State \\ 2. Department of Educational Foundations, University of Nigeria, Nsukka
}

\begin{abstract}
The study sought to determine the extent of usage of Igbo Language as a medium of instruction and interaction in the lower basic classes in Enugu North Education Zone, Enugu State, Nigeria. Four research questions guided the study. The design was a descriptive survey. The population consisted of 2069 teachers (198 Head teachers and 1,871 Classroom teachers) in Enugu North Education zone of Enugu state, public and private schools inclusive. The sample was 200 teachers (50 Head teachers and 150 Class teachers) drawn from the population using stratified random sampling technique. The instrument used for data collection was researchers developed questionnaire titled "Mother-Tongue Based Schooling Questionnaire" (MTBSQ) which was face validated by experts in Igbo Language and Measurement and Evaluation from Federal College of Education, Kotangora, Niger State. The reliability estimate of MTBSQ established using Pearson's co-efficient formula was 0.86 . Findings indicated very low extent of the use of mother tongue (Igbo Language) as a medium of instruction and interaction; schools and parents preferred the use of English Language (L2) as a medium of instruction and interaction; and indigenous materials and textbooks in mother tongue were not available or used for instruction. By educational implication, this is a negation of the National policy stipulation on the usage of mother-tongue for instruction in Nigerian schools. The researchers therefore recommended that Government should lay emphasis on total implementation of the National Policy on Education with particular reference to usage of mother-tongue as a medium of instruction in pre-primary and primary schools in Nigeria. Also, parents and care-givers should be educated on the need for them to interact with children in their mother-tongue.
\end{abstract}

Keywords: early childhood education, future generation, mother tongue.

DOI: $10.7176 / \mathrm{JEP} / 10-23-11$

Publication date: August $31^{\text {st }} 2019$

\section{Introduction}

Nigeria is a multilingual nation. The total number of languages spoken in Nigeria is 415 and about $6.1 \%$ of the total spoken languages in the world. Grimes (2000) observed that out of the 6,809 oral languages spoken in 228 countries of the world, $415(6.1 \%)$ is spoken in Nigeria, making Nigeria to rank third after New Guinea with 850 languages and Indonesia with 650 languages. Language is very important in human existence. It is not only a fullfledged identity of the human person, but also one of the effective means of communication and understanding in the classroom and a purveyor of people's culture.

All the 415 spoken Nigerian languages are either identified as mother tongue, first language (L1), native language, or indigenous language. Mother tongue is a traditional term for a person's native language, that is, a language learned from birth. Contemporary linguists and educators commonly use the term L1 to refer to a first or native language (the mother tongue), and the term L2 to refer to a second language or a foreign language that is being studied. The mother tongue allows the child to verbalize his or her thoughts and to be in harmony with the world around him. Thus the use of foreign language in school suddenly puts the child in a situation of regression and confusion. School learning becomes more difficult when the learners speak a totally different language at home. This creates a symbolic break between the two major institutions of socialization which are school and the family. Identifying mother tongue as first language connotes the existence of second language (L2) third language (L3) and so on. Romaine (1994) identified the origin of L2 to acculturation as a community that was once monolingual becomes bilingual as a result of contact with another language. The usage of two languages or bilingual education describes any system of education in which, at a given moment in time and for a varying amount of time, simultaneously or consecutively, instruction is planned and given in at least two languages (Hamers \& Blanc, 1992).

Hamers and Blanc (1992) have identified three categories of bilingual education as where:

- Instruction is given in both languages;

- Instruction is given first in the first language, and pupils taught until such a time that they are able to use the second language as a medium of learning;

- The largest part of instruction is given through the second language, and the first language is introduced laterfirst as a subject and later as a medium of instruction.

United Nations Education, Science and Culture Organization (UNESCO, 2005) recommended a trilingual 
policy for multilingual nations to include:

a) An international language which enable the individual participate in world economy and other network (For example English or French in former colonial territorial);

b) A lingual franca, that is, a local language which facilitates communication among people speaking different languages in the country; and

c) A mother tongue

Bearing in mind this trilingual policy, egalitarian multilingualism as supported by some scholars provides for a balanced and equal relationship among languages so as to give due recognition to the linguistic rights of the speakers of all languages. This means that the contest of survival of languages is an ongoing strife. According to Mba (2010), a people that strive and succeed in developing its language will join in the comity of nations whose official languages are spoken by many. On the other hand, others who do not strive to preserve and promote their language as in the case of Igbo and other minority languages in Nigeria will be razed off through committance of linguistic genocide.

The National Policy on Education (FRN, 2014) appreciate and recognize this trilingual policy and thus has English Language as the language of wider communication, Hausa, Igbo or Yoruba as the lingua franca and 415 indigenous languages as the mother tongues. As a means of promoting mother tongue, the Federal Republic of Nigeria advocates for Mother-tongue Based schooling for pupils in pre-primary and primary schools. According to FRN (2014), the medium of instruction will be principally the mother-tongue or the language of the immediate community. The language of education in multilingual societies has always been a matter of concern to educators and educational planners. Ouadraogo (2000) has pointed out that education and language issues are very complex in Africa because of her multi-ethnic and multi-lingual nature. The situation is even more severe when the official language of the nation is different from any of the indigenous languages as in the case of Nigeria. There is always controversy over which language to use in school especially at the lower primary level in multilingual societies. The controversy is anticipated because the lower basic class is the foundation stage of the education process. It must be noted that mother tongue education is a right as well as a need for every child (Pattanayak, 1986). Denying the child the use of his/her native language in education is not only committing the crime of linguistic genocide in education (Skutnabb-Kangas, 2000), but also bringing much confusion in the child as the child battles with which language to learn and use. The use of the child's first language in education has been shown to enhance the academic, linguistic, and cognitive achievement of learners (Baker, 2001). Lewelling, (1991) is of the view that the level of first language proficiency has a direct influence on second language development as well as cognitive development and growth. According to Snow and Hoefnagel-Hohle, (1978), the older the age of the learner, the better they learn the second language because they have achieved a high level of cognitive maturity in the L1.

Instruction through a language that learners do not speak has been called "submersion" (Skutnabb-Kangas 2000), because it is analogous to holding learners under water without teaching them how to swim. Compounded by chronic difficulties such as low levels of teacher education, poorly designed or inappropriate curricula and lack of adequate school facilities; submersion makes both learning and teaching extremely difficult; particularly when the language of instruction is also foreign to the teacher. Beyond instruction, using L2 hampers African development, cultural freedom and total emancipation cannot be experienced or developed when the language in which people are "most creative and innovative" is not the language of instruction nor used.

Research has shown that children's first language is the optimal language for literacy and learning throughout primary school (UNESCO, 2008a). But in spite of growing evidence, many educational systems around the world insist on exclusive use of one or sometimes several privileged languages instead of the mother tongue. Many linguistic groups are becoming vocal about the need to ensure that the child keeps their linguistic heritage. Some governments, such as in the Philippines, have recently established language-in-education policies that embrace the use of children's first languages for instruction. Also UNESCO has encouraged mother tongue instruction in primary education since 1953. UNESCO, (1953) thus highlights the advantages of mother tongue education right from the start to include:

1. $\quad$ children are more likely to enroll and succeed in school (Kosonen, 2005);

2. parents are more likely to communicate with teachers and participate in their children's learning (Benson, 2002); and

3 girls and rural children with less exposure to a dominant language stay in school longer and repeat grades less often (Hovens, 2002).

The above findings suggest that teaching and learning is easier when done in the mother tongue at the lower basic stage of education. The "Ife six-year project" discovered amidst this bilingual policy that pupils who were taught in Yoruba performed better in all the subjects except English than pupils taught in English. This result shows that instruction using the mother tongue is a better practice especially at the earlier stages than using L2. This is because both the teacher and the learners are at home and conversant with the mother tongue. Also, the resources for instruction within the environment are easier, cheaper and assessable. In Mali, the child's mother tongue is used as the language of instruction throughout primary school and the second language is taught in such 
a way that the learners become functionally bilingual. It is lamentable that in Africa, bilingualism has tended to be subtractive because the socio-cultural attributes of indigenous languages have been denigrated in favour of those of the colonial language, which is considered to be more prestigious. This has even resulted in some Africans, educated through the medium of a colonial language, shunning their mother tongues (Sure \& Webb, 2000). The above situation has had some of the following serious consequences for educational development in Africa. Indigenous languages have not been taken seriously as subjects of study. Too much emphasis has been placed on proficiency in English, which in many cases, is introduced to children from the first day of school. Proficiency in the mother tongue is, in some cases, jeopardized because teachers and parents focus on learning English at school and home. It is saddening that, in some cases, children come to school proficient in their mother-tongues but soon begin to lose this as the focus is shifted to developing proficiency in English both at school and home. Sure and Webb (2000) observe that, although the use of colonial languages in education has led to serious problems, it has also brought with it enormous advantages such as access to knowledge, creativity and entertainment of the entire western world, as well as global trade and commerce. Sure and Webb further argued that European languages have become an integral part of the lives of the African people and are indeed resources to be nurtured and developed.

Despite the above merits, Ohiri-Aniche (2006) in a study discovered high marginalization of indigenous language for instruction in Lagos State primary schools. Similar studies on the use and the role of mother tongue abound in other regions, but little or nothing is done in Eastern part of Nigeria. The language transferability theory and thresholds theory advocates for use of mother tongue for instruction. According to language transferability theory, languages have a common underlying proficiency, and the concepts understood in one language are transferable to the other. Transferring from L1 to L2 is theoretically and empirically more probable. The L1 serves as background knowledge, preexisting knowledge upon which inferences and predictions can be made to facilitate transfer (Saville-Troike, 1988). In all considerations, it is easier and more cost effective to invest in L1 to promote transfer to L2 than it is to do the opposite. Hakuta (1990), points out that native language proficiency is a strong indicator of second language development. In support of mother tongue usage for instructions, the Threshold theory holds that there is a level of L1 proficiency that a child needs to attain to avoid the negative consequences of using two languages. This suggests that if the child is prematurely transitioned into L2, the consequences may be detrimental to the child's cognitive development and academic achievement.

Mother tongue based schooling goes beyond instruction, interaction and continuity of the language. Williams and Snipper (1990), noted that language encompasses not only communication, but also heritage, culture, and feelings. It is therefore, important to note that maintaining a speakers' native language has an affective dimension of enhancing their self-concepts and pride in their cultural background and identity. Also Kembo (2000) opines that cognitive and affective development occurs more effectively in a language that the learner knows very well. It is also argued that learning in general (including second language learning) occurs more effectively if the required cognitive development (language skills) has already been acquired through the use of a first language as a language of learning. Cummins (1984) argued that optimal first language education provides a rich cognitive preparation for the acquisition of a second language and that the literacy and cognitive skills already acquired in the first language provide easy transition to the next level where second-language becomes the of medium instruction and learning.

\section{Problem of the study}

Notwithstanding the bilingual policy of UNESCO 1953 and the Mother-Tongue based Schooling Policy of FRN, there seems to be some secret plots exhibited through attitude or action in the name of globalization and development to lay to permanent rest the mother tongue (L1), while promoting or indigenizing the foreign languages (L2). This attitude and actions geared towards linguistic genocide of mother tongue (L1) starts according to Uzoezie (2008) in most homes as parents, grandparents and their children have problems of mutual communication because each of the three speaks different languages at home. The scenario can be illustrated thus: Grandparent

Parent Children

\section{(L1 only) \\ L1 and English \\ English and/or little or no L1}

The grandparents speak L1, the parents speak L1 and English and the children speak English with little or no L1. The above scenario forecasts total disintegration and complete demise of L1 with time if nothing is done. If allowed to continue, the child will be more confused when the language used for instruction becomes at variance to the language used at home and during play. With the above complex scenario of confusion of the language to use, preference of L2 and laying to final rest L1, the study intends to examine mother-tongue based schooling, as a key for quality education. The problem of the study put in question form is: to what extent is mother-tongue used as a medium of instruction and interaction in the lower basic classes of Nigerian schools? The study tends to reawaken mother tongue usage in pupils schools in accordance to the language policy of FRN (2014) and to avert the danger of language confusion amongst pupils through combing so many languages at this stage and extinction of L1. 


\section{Research Questions}

The following questions guided the study:

1. What is the extent of the use of mother tongue as a language of instruction and interaction?

2. What is the extent of availability of textbooks in the mother-tongue for pupil usage?

3. What is the extent of availability and usage of indigenous resource materials for instruction?

4. What are the constraints on the use of mother-tongue as a language of instruction and interaction schools?

\section{Method}

The study adopted a descriptive survey research design. The study was carried out in Enugu North Education Zone of Enugu State, Nigeria using the head teachers and class teachers in both public and private schools. The population was 2069 consisting of 198 Head teachers and 1,871 Classroom teachers in Enugu North Education Zone, (source: Ministry of Education, Enugu, 2013). The sample size of the study comprised of 200 (50 head teachers and 150 class teachers) drawn from the population using stratified random sampling technique. The sample was made up as follows: one head teacher and three teachers from each of the 50 schools in the study area.

The instrument for data collection was the researcher structured questionnaire titled "Mother-Tongue Based Schooling, questionnaire (MTBSQ). The instrument had four sections which sought information on: extent of usage of mother tongue as a language of instruction and interaction; availability of textbooks on mother tongue; availability of resource material; and the constraints on the use of mother-tongue. The instrument was pilot tested and a reliability estimate of 0.86 was established through Cronbach alpha formula. The instrument was structured on a four point scale of very great extent $(\mathrm{VGE}=4)$; Great Extent $(\mathrm{GE}=3)$, Low Extent $(\mathrm{LE}=2)$ and VLE Extent $(\mathrm{VLE}=1)$, and validated by experts in Igbo Language and Measurement and Evaluation, both from Federal College of Education, Kotangora, Niger State. Mean and Standard Deviation scores were used to analyze the data. The result was interpreted using the mean score of 2.49 and below to mean Low Extent and 2.50 and above to mean Great Extent.

\section{Results}

Table 1: Mean rating of the extent to which mother tongue is used for instruction and interaction in the school

\begin{tabular}{|c|c|c|c|c|c|c|c|c|c|}
\hline \multirow[t]{3}{*}{$\mathrm{SN}$} & \multirow[t]{3}{*}{ ITEMS } & \multicolumn{4}{|c|}{ PUBLIC SCHOOLS } & \multicolumn{4}{|c|}{ PRIVATE SCHOOLS } \\
\hline & & \multicolumn{2}{|c|}{$\begin{array}{l}\text { H/TEACHERS } \\
\quad \mathrm{N}=35\end{array}$} & \multicolumn{2}{|c|}{$\begin{array}{c}\text { C/TEACHERS } \\
\mathrm{N}=105\end{array}$} & \multicolumn{2}{|c|}{$\begin{array}{l}\text { H/TEACHERS } \\
\quad \mathrm{N}=15\end{array}$} & \multicolumn{2}{|c|}{$\begin{array}{c}\text { C/TEACHERS } \\
\quad \mathrm{N}=45\end{array}$} \\
\hline & & $\mathrm{X}$ & SD & $\mathrm{X}$ & SD & $\mathrm{X}$ & SD & $\mathrm{X}$ & SD \\
\hline 1 & $\begin{array}{l}\text { Mother tongue is used to teach all } \\
\text { the subjects in lower basic classe }\end{array}$ & 1.4 & 0.18 & 1.84 & 0.35 & 1 & 0.08 & 1.2 & 0.07 \\
\hline 2. & $\begin{array}{l}\text { Mother tongue is used to teach the } \\
\text { major subjects like English and } \\
\text { maths }\end{array}$ & 1.22 & 0.10 & 1.51 & 0.25 & 1.26 & 0.12 & 1.69 & 0.08 \\
\hline 3. & $\begin{array}{l}\text { Teachers Communicate with } \\
\text { pupils in Igbo language }\end{array}$ & 3.08 & 0.75 & 3.60 & 0.89 & 2 & 0.41 & 1.57 & 0.08 \\
\hline 4 & $\begin{array}{l}\text { Encourages pupils to converse in } \\
\text { Igbo language }\end{array}$ & 1.45 & 0.2 & 1.59 & 0.37 & 1.66 & 0.28 & 1.64 & 0.09 \\
\hline 5 & $\begin{array}{l}\text { Use Igbo during meetings and } \\
\text { other functions }\end{array}$ & 1.17 & 0.08 & 1.68 & 0.29 & 1.86 & 0.36 & 1.08 & 0.03 \\
\hline 6 & $\begin{array}{l}\text { Teachers communicate among } \\
\text { themselves in Igbo language at } \\
\text { school }\end{array}$ & 2.8 & 0.67 & 3.47 & 0.86 & 3.13 & 0.76 & 3.13 & 0.8 \\
\hline 7 & $\begin{array}{l}\text { In the presence of pupils, teachers } \\
\text { communicate with parents and } \\
\text { others in Igbo language }\end{array}$ & 2.74 & 0.66 & 3.01 & 0.73 & 3 & 0.74 & 2.53 & 0.21 \\
\hline 8 & $\begin{array}{l}\text { All teachers can speak Igbo } \\
\text { language fluently }\end{array}$ & 2.51 & 0.58 & 2.26 & 0.5 & 2.33 & 0.52 & 1.95 & 0.09 \\
\hline 9 & $\begin{array}{l}\text { All pupils can speak their mother } \\
\text { tongue very well }\end{array}$ & 2.69 & 0.64 & 2.4 & 0.54 & 2.06 & 0.69 & 2.24 & 0.6 \\
\hline 10 & $\begin{array}{l}\text { Speaking of Igbo language is } \\
\text { banned in the school }\end{array}$ & 2.25 & 0.6 & 2.14 & 0.46 & 2.73 & 0.65 & 2.56 & 0.68 \\
\hline 11 & $\begin{array}{l}\text { There is a cultural programme in } \\
\text { the school }\end{array}$ & 1.14 & 0.06 & 2.13 & 0.45 & 2.53 & 0.39 & 2.68 & 0.71 \\
\hline 12 & $\begin{array}{l}\text { There is an Igbo speaking day } \\
\text { mapped out every week in the } \\
\text { school }\end{array}$ & 2.71 & 0.64 & 1.88 & 0.37 & 2.51 & 0.38 & 2.53 & 0.21 \\
\hline & Cluster & 2.09 & 0.43 & 2.29 & 0.51 & 2.17 & 0.45 & 2.07 & 0.30 \\
\hline
\end{tabular}

In table, the mean response of head teaches and class teachers in both public and private schools indicate very low extent of usage of mother-tongue as a language of instruction and interaction in schools. This is evident in 
their mean response of 2.09 and 2.29 for public schools and 2.17 and 0.30 for private schools.

Table 2: Mean ratings of the extent to which textbooks are available in the mother-tongue.

\begin{tabular}{|c|c|c|c|c|c|c|c|c|c|}
\hline \multirow[t]{4}{*}{ SN } & \multirow[t]{4}{*}{ ITEMS } & \multicolumn{4}{|c|}{ PUBLIC SCHOOLS } & \multicolumn{4}{|c|}{ PRIVATE SCHOOLS } \\
\hline & & \multirow{2}{*}{\multicolumn{2}{|c|}{$\begin{array}{l}\text { H/TEACHERS } \\
\mathrm{N}=35\end{array}$}} & \multirow{2}{*}{\multicolumn{2}{|c|}{$\begin{array}{l}\text { C/TEACHERS } \\
\mathrm{N}=105\end{array}$}} & \multirow{2}{*}{\multicolumn{2}{|c|}{$\begin{array}{l}\mathrm{H} / \text { TEACHERS } \\
\mathrm{N}=15\end{array}$}} & \multirow{2}{*}{\multicolumn{2}{|c|}{$\begin{array}{l}\text { C/TEACHERS } \\
\mathrm{N}=45\end{array}$}} \\
\hline & & & & & & & & & \\
\hline & & $\mathrm{x}$ & SD & $\mathrm{x}$ & SD & $\mathrm{x}$ & SD & $\mathrm{X}$ & SD \\
\hline 1 & $\begin{array}{l}\text { All the subjects have text } \\
\text { books in Igbo language }\end{array}$ & 1.19 & 0.09 & 1.39 & 0.17 & 1.66 & 0.28 & 1.62 & 0.23 \\
\hline 2 & $\begin{array}{l}\text { Only the core subjects have } \\
\text { books in Igbo language }\end{array}$ & 1.34 & 0.14 & 1.86 & 0.36 & 1.73 & 0.31 & 1.55 & 0.21 \\
\hline 3 & $\begin{array}{l}\text { There is an Igbo dictionary for } \\
\text { pupils usage }\end{array}$ & 1.71 & 0.30 & 1.81 & 0.34 & 2.0 & 0.41 & 1.89 & 0.32 \\
\hline 4 & $\begin{array}{l}\text { Some of the textbook in Igbo } \\
\text { language are not properly } \\
\text { written }\end{array}$ & 1.05 & 0.01 & 1.84 & 0.35 & 1.86 & 0.34 & 1.64 & 0.24 \\
\hline 5 & $\begin{array}{l}\text { Books in Igbo language are not } \\
\text { affordable }\end{array}$ & 1.77 & 0.33 & 2.21 & 0.48 & 2 & 0.41 & 2.15 & 0.37 \\
\hline 6 & $\begin{array}{l}\text { There are no textbooks in Igbo } \\
\text { language }\end{array}$ & 3.02 & 1.77 & 3.03 & 0.74 & 2.4 & 0.43 & 2.64 & 0.57 \\
\hline & Cluster & 1.68 & 0.44 & 2.02 & 0.41 & 1.94 & 0.36 & 1.75 & 0.32 \\
\hline
\end{tabular}

Data in the table 2 indicates that the extent of availability of textbooks in Igbo language for pupils' usage and instruction is very low. Apart from item 6 with mean scores of 3.02 and 3.03 for head teachers and class teachers of public schools; 2.40 and 2.64 for head teachers and class teachers of private schools respectively, all other items have mean scores below 2.45. The cluster means of 1.68 and 2.02 for public schools and 1.94 and 1.75 for private schools further attest to the very low availability of textbooks in mother-tongue.

Table 3: Mean rating of the extent to which indigenous instructional materials are available and used during instruction.

\begin{tabular}{|c|c|c|c|c|c|c|c|c|c|}
\hline \multirow[t]{4}{*}{ SN } & \multirow[t]{4}{*}{ ITEMS } & \multicolumn{4}{|c|}{ PUBLIC SCHOOLS } & \multicolumn{4}{|c|}{ PRIVATE SCHOOLS } \\
\hline & & \multirow{2}{*}{\multicolumn{2}{|c|}{$\begin{array}{l}\mathrm{H} / \mathrm{TEACHERS} \\
\mathrm{N}=35\end{array}$}} & \multirow{2}{*}{\multicolumn{2}{|c|}{$\begin{array}{l}\text { C/TEACHERS } \\
\mathrm{N}=105\end{array}$}} & \multirow{2}{*}{\multicolumn{2}{|c|}{$\begin{array}{l}\mathrm{H} / \text { TEACHERS } \\
\mathrm{N}=15\end{array}$}} & \multirow{2}{*}{\multicolumn{2}{|c|}{$\begin{array}{l}\mathrm{C} / \text { TEACHERS } \\
\mathrm{N}=45\end{array}$}} \\
\hline & & & & & & & & & \\
\hline & & $\mathrm{x}$ & SD & $\mathrm{x}$ & SD & $\mathrm{X}$ & SD & $\mathrm{X}$ & SD \\
\hline 1 & $\begin{array}{l}\text { There is enough indigenous } \\
\text { instructional materials }\end{array}$ & 2.22 & 0.48 & 1.70 & 0.30 & 2.32 & 0.52 & 2.31 & 0.51 \\
\hline 2 & $\begin{array}{l}\text { Teachers gets their indigenous } \\
\text { instructional materials from the } \\
\text { locality }\end{array}$ & 2.14 & 0.46 & 2.01 & 0.41 & 2.26 & 0.50 & 2.42 & 0.55 \\
\hline 3 & $\begin{array}{l}\text { Teachers do not use foreign } \\
\text { materials during instruction }\end{array}$ & 2.74 & 0.65 & 3.08 & 0.75 & 3.26 & 0.81 & 2.71 & 0.64 \\
\hline 4 & $\begin{array}{l}\text { Teachers ask pupils to bring } \\
\text { local materials from their homes }\end{array}$ & 2.74 & 0.65 & 2.30 & 0.51 & 2.53 & 0.59 & 2.2 & 0.48 \\
\hline 5 & $\begin{array}{l}\text { Local instructional materials are } \\
\text { not available }\end{array}$ & 1.91 & 0.38 & 1.92 & 0.38 & 1.86 & 0.35 & 2.11 & 0.45 \\
\hline 6 & \begin{tabular}{lllr} 
Indigenous & & \multicolumn{2}{c}{ instructional } \\
materials are & cheap and \\
affordable & & &
\end{tabular} & 2.31 & 0.51 & 2.59 & 0.60 & 2.18 & 0.47 & 2.48 & 0.57 \\
\hline & Cluster & 2.34 & 0.49 & 2.27 & 0.49 & 2.40 & 0.54 & 2.37 & 0.53 \\
\hline
\end{tabular}

Table 3 presents the response of the respondents on the extent to which indigenous instructional materials are available and used during instruction. The cluster of 2.34 and 2.27 for public schools and 2.40 and 2.37 for private schools indicate very low extent of availability and use of indigenous instructional materials in schools. 
Table 4: Mean rating of respondents on the constraints militating against the usage of mother tongue for instruction.

\begin{tabular}{|c|c|c|c|c|c|c|c|c|c|}
\hline \multirow[t]{3}{*}{$\mathrm{SN}$} & \multirow[t]{3}{*}{ ITEMS } & \multicolumn{4}{|c|}{ PUBLIC SCHOOLS } & \multicolumn{4}{|c|}{ PRIVATE SCHOOLS } \\
\hline & & \multicolumn{2}{|c|}{ H/TEACHERS } & \multicolumn{2}{|c|}{ C/TEACHERS } & \multicolumn{2}{|c|}{ H/TEACHERS } & \multicolumn{2}{|c|}{ C/TEACHERS } \\
\hline & & $\mathrm{X}$ & SD & $\mathrm{x}$ & SD & $\mathrm{x}$ & SD & $\mathrm{x}$ & SD \\
\hline 1 & $\begin{array}{l}\text { Schools prefer the use of English } \\
\text { than Igbo language }\end{array}$ & 3.45 & 0.85 & 3.32 & 0.82 & 3.53 & 0.87 & 2.75 & 0.65 \\
\hline 2 & $\begin{array}{l}\text { Schools prefer pupils to learn } \\
\text { and speak English language very } \\
\text { well }\end{array}$ & 3.51 & 0.87 & 3.34 & 0.80 & 3.6 & 0.89 & 3.44 & 0.76 \\
\hline 3 & $\begin{array}{l}\text { Parents do not like their children } \\
\text { to be taught with Igbo language }\end{array}$ & 3.17 & 0.78 & 3.48 & 0.86 & 3.6 & 0.89 & 3.64 & 0.82 \\
\hline 4 & $\begin{array}{l}\text { Parents prefer their children } \\
\text { mastering English than Igbo } \\
\text { language }\end{array}$ & 3.34 & 0.82 & 3.27 & 0.78 & 3.2 & 0.78 & 2.51 & 0.45 \\
\hline 5 & $\begin{array}{l}\text { Igbo language is not used } \\
\text { because the classes contain } \\
\text { children from different language } \\
\text { background }\end{array}$ & 3.45 & 0.85 & 3.52 & 0.87 & 2.86 & 0.69 & 2.62 & 0.54 \\
\hline 6 & $\begin{array}{l}\text { The schools lack trained teachers } \\
\text { that are able to teach in Igbo } \\
\text { language }\end{array}$ & 3.05 & 0.74 & 3.48 & 0.86 & 3.13 & 0.76 & 2.73 & 0.63 \\
\hline 7 & $\begin{array}{l}\text { There is lack of Igbo language } \\
\text { text books }\end{array}$ & 3 & 0.73 & 3 & 0.75 & 2.73 & 0.65 & 2.82 & 0.67 \\
\hline 8 & $\begin{array}{l}\text { There is lack of instructional } \\
\text { materials of Igbo origin and } \\
\text { background }\end{array}$ & 2.94 & 0.71 & 3.4 & 0.84 & 3.2 & 0.78 & 2.91 & 0.69 \\
\hline 9 & $\begin{array}{l}\text { Igbo language lack adequate } \\
\text { words and expressions to qualify } \\
\text { its usage for instruction }\end{array}$ & 3.06 & 0.75 & 2.63 & 0.67 & 2.33 & 0.52 & 2.97 & 0.71 \\
\hline 10 & $\begin{array}{l}\text { The government does not give } \\
\text { adequate support to the usage of } \\
\text { Igbo language for instruction in } \\
\text { schools }\end{array}$ & 2.68 & 0.63 & 3.53 & 0.88 & 2.8 & 0.67 & 2.6 & 0.61 \\
\hline 11 & $\begin{array}{l}\text { ost Igbo people discourages the } \\
\text { usage of Igbo language in } \\
\text { schools }\end{array}$ & 3.31 & 0.81 & 2.81 & 0.67 & 2.53 & 0.59 & 2.82 & 0.67 \\
\hline & Cluster & 3.17 & 0.78 & 3.25 & 0.8 & $\mathbf{3 . 0 5}$ & 0.74 & 2.89 & 0.65 \\
\hline
\end{tabular}

Table 4 presents the responses of respondents on the constraining factors on the use of mother-tongue for instruction and interaction in schools. The cluster means of 3.17 and 3.25 for public schools and 3.05 and 2.29 for private schools indicate that the respondents identified all the items in table 4 as a constraining factor.

\section{Discussion}

Results indicate very low extent of usage of mother tongue as a language of instruction and interaction in education of pupils in lower basic classes. This is evident from the cluster mean scores of 2.09 and 2.29 for public schools and 2.17 and 2.07 for private schools as obtained from the responses of head teachers and class teachers. The finding of this study contravenes the provision of FRN (2014) in her NPE which states that the medium of instruction should be the mother-tongue or the language of the immediate community and that the language of the immediate community shall be taught as subjects in the pre-primary and primary schools. The finding of the study 
goes to explain the findings of Ohiri-Aniche (2006) that about $80 \%$ of the pupils are hardly competent in their ancestral languages. It also negates the various research evidence of positive impact of mother-tongue based instruction at the lower level of the child's learning, (Ohiri-Aniche, 2006; Prah, 200; Mbah, 2010: and Webb, 2000).

The results of the study also indicate dearth of textbooks in Igbo Language and other indigenous instructional materials for use in schools. This is evident from the cluster mean scores of both head teachers and class teachers in both public and private school which are (2.34 and 2.27) and ( 2.40 and 2.37) respectively. The results of the study also conform with the findings of Ohiri-Aniche that books and other instructional materials such as cassettes, recorder, CDs, films, videos etc, should be made available in local languages and that the books must be age appropriate to promote intellectual, physical, emotional and social development of children.

Finally, the results of the study showed that all the 11 items in table four to a very great extent are constraint on the use of Igbo language for instruction and interaction in schools. This is evident from the cluster mean scores of 3.17 and $3.25 ; 3.05$ and 2.89 , for head teachers and class teachers from public and private schools respectively. The result is in line with the findings of Ohiri-Auche (2006) that one of the constraints to the usage of mothertongue for instruction is the preference of the schools and parents to assisting pupils learning English first at the expense of their mother tongue.

\section{Conclusion and recommendations}

In line with the findings of the study, it is obvious that Igbo language is not being used for instruction in the lower basic classes in Eastern part of Nigeria. Textbooks and other instructional materials in Igbo language are greatly lacking. The major constraints on the use of Igbo Language in education of children in the lower basic class included: poor attitude of the government in providing materials and trained teachers; poor attitude of parents towards Igbo language evident in the superiority placed on English language over Igbo language among others.

It is therefore recommended that Government lay emphasis on total implementation of the National Policy on Education with particular reference to usage of mother-tongue as a medium of instruction in pre-primary and primary schools in Nigeria. Also, parents and care-givers should be educated on the need for them to interact with children in their mother-tongue. Colleges of Education and teachers training colleges should teach would be teachers in the 3 major languages of Nigeria

\section{Reference}

Akinnaso, F.N. (1991). On the Mother tongue education policy in Nigeria. Educational Review, 43 (10), 89-106.

Baker, Colin (2001). Foundations of bilingual education (3rd edition). Clevedon, England: Multilingual Matters Ltd.

Benson, C. (1994). Teaching beginning literacy in the 'mother tongue'. Unpublished doctoral dissertation. Los Angeles: UCLA.

FRN (2014). National Policy on Education. Lagos: NERDC.

Grimes, B. (Ed). (2000). Ethnologue, Language of the world (14 $4^{\text {th }}$ Edition), Texas:International Linguistic center. Hakuta, K. (1990). Bilingualism and bilingual education: A research perspective. Focus No. 1.

Hamers, J., \& Blanc, M. (1992). Bilinguality and bilingualism. Cambridge, UK: Cambridge University Press.

Hovens, M. (2002). Bilingual education in West Africa: Does it work? International Journal of Bilingual Education and Bilingualism, 5 (5), 249-266.

Kembo, J. (2000). Language in education and language learning in Africa.In V. Webb \& K. Sure (Eds.), African voices. Oxford, UK: Oxford University Press.

Kosonen, K. (2005). Education in local languages: Policy and practice in Southeast Asia. First languages first: Community-based literacy programmes for minority language contexts in Asia. Bangkok: UNESCO.

Krashen, S. and Terrell, G. C. (1983). Language learning. A journal of Applied Linguistics, 39 (4), 155-156.

Lewelling, V. W. (1991). Academic achievement in second language. Eric Clearinghouse on Languages and Linguistics. Washington DC. (ERIC Document Reproduction Service No. ED 329130)

Mbah, B. M. (2010). The role of the mother tongue/language of the immediate community in the socio-economic development of Nigeria. Being a lead paper presented during the $14^{\text {th }}$ Annual conferenceof the Association of Nigeria Language Teachers, Federal College of Education, Kontagora, Niger State.

Ohiri-Aniche, C. (2006). Marginalization of Nigerian Languages in Nursery and Primary schools: Path to indigenous Language death in Nigeria. Being a paper presented at the $20^{\text {th }}$ annual conference of Linguistic Association of Nigeria, NERDC.

Ouedraogo, R. M. (2000). Language planning and language policies in some selected West African countries. Burkina Faso: IICBA.

Patanayak. D.P. (1986). Educational Use of the Mother Tongue. In Bernard Spolsky (Ed.), Language and Education in Multilingual Settings-(pp. 5-15). California: College-Hill Press.

Romaine, S. (1994). Language in Society: An Introduction to Sociolinguistics. Oxford: Oxford University Press. 
Saville-Troike, M. (1988). Teaching and testing for academic achievement: Perspective on an ill-structured domain. (Unpublished manuscript).

Skutnabb-Kangas, T. (2000). Linguistic Genocide - Worldwide Diversity and Human Rights. New Jersey: Lawrence Eribaum Associates.

Snow, C. E. and Hoefnagel-Hohle, M. (1978). The critical period for language acquisition: Evidence from second language learning. Child Development 49, 1114-1128.

Sure, K., \& Webb, V. (2000) Languages in competition. In V. Webb \& K. Sure (Eds.), African voices. Oxford, UK: Oxford University Press.

UNESCO (1953). The use of vernacular languages in education. Report of the UNESCO Meeting of Specialists (1951). Monograph on Fundamental Education VII. Paris: UNESCO.

UNESCO (2008a). Mother Tongue Matters: Local Language as a Key to Effective Learning. Paris: UNESCO.

UNESCO Bangkok (2005). Advocacy brief on mother tongue-based teaching and education for girls. Bangkok: UNESCO.

Uzoezie, R. U. (2008). The hegemonic face of Linguistic dinosaur: English Vs Nigeria's Indigenous Languages. In Iwu, I., Ohiri-Aniche, C. \& Nnabuihe, C. (eds).Udezuluigbo: A Festschrift in honor of Sam Uzochukwu. Lagos: Green Olive Pub.

Williams, J., \& Snipper, G. (1990). Literacy and bilingualism. London: Longman. 